\title{
Lead, Cadmium, Zinc, and Copper Bioavailability in the Soil-Plant-Animal System in a Polluted Area
}

\author{
Violina R. Angelova ${ }^{1, \star}$, Radka V. Ivanova ${ }^{2}$, Jivko M. Todorov², \\ and Krasimir I. Ivanov ${ }^{1}$ \\ ${ }^{1}$ Department of Chemistry and ${ }^{2}$ Department of Plant Science, Agricultural University, \\ Plovdiv, Bulgaria \\ E-mail: vileriz@yahoo.com
}

Received July 20, 2009; Revised February 3, 2010; Accepted February 3, 2010; Published February 17, 2010

A comparative research study on the bioavailability of $\mathrm{Pb}, \mathrm{Cd}, \mathrm{Zn}$, and $\mathrm{Cu}$ in the soilplant-animal-system was carried out. The connection between the total quantity and the mobile forms of $\mathrm{Pb}, \mathrm{Cd}, \mathrm{Zn}$, and $\mathrm{Cu}$ in soils with different levels of contamination; the transition of these metals into rapeseed; and their assimilation by rabbits fed with a food that consisted mainly of rapeseed was studied. It was established that the absorption of heavy metals by the rapeseed definitely has a selective character, as the affinity towards $\mathrm{Zn}$ is most strongly expressed. The accumulation of $\mathrm{Pb}, \mathrm{Cd}, \mathrm{Zn}$, and $\mathrm{Cu}$ in the organs of the rapeseed occurs in the following order: inflorescences $>$ leaves $>$ stems. A direct connection between the quantity of the mobile forms and their accumulation in the plants was not found. The environmental contamination has a significant effect on heavy metal levels and distribution, as the largest quantity of all four elements is accumulated in the kidneys and liver. A well-expressed impact of the level of $\mathrm{Cd}$ contamination on the absorption of essential trace metals $(\mathrm{Zn}$ and $\mathrm{Cu})$ and their accumulation into some of the organs of the animals was found.

KEYWORDS: heavy metals, polluted soils, intake, bioaccumulation, rapeseed, rabbits

\section{INTRODUCTION}

Toxic metals are natural components of the environment, but human activities, notably industrial and mining processes, have been responsible for the wider diffusion of these elements. The transport, residence time, and fate of pollutants in an ecosystem are serious social concerns. Due to the highly complex behavior of trace elements within an ecosystem, studies are usually conducted separately for air, water, soil, and biota[1,2]. Plants are good soil quality indicators as they directly reflect air quality. Since plants can naturally absorb pollutants from their local environment, their chemical composition can indicate the degree of disturbance when assessed against background values obtained from unpolluted vegetation. Plants adapt to the great variability of chemical properties within their environment, and are an intermediate medium through which trace elements in soil, water, or air move to animals and humans[2]. 
Cadmium $(\mathrm{Cd})$ and lead $(\mathrm{Pb})$ are nonessential elements that are toxic to plants and animals, while zinc (Zn) and copper $(\mathrm{Cu})$ play essential metabolic roles in plants and animals[3]. It is known that only a small amount of the total $\mathrm{Pb}$ in soils may be taken up by plants, and the translocation of $\mathrm{Pb}$ from roots to tops is greatly limited[1]. $\mathrm{Cd}, \mathrm{Zn}$, and $\mathrm{Cu}$ can be more readily taken up by plants and relatively high concentrations may occur in crops for human consumption. The amount of $\mathrm{Pb}, \mathrm{Cd}$, and $\mathrm{Zn}$ taken up by plants depends on the total amounts in the soil and their availability[4]. The availability of heavy metals is influenced by a wide range of factors, including soil $\mathrm{pH}$, organic matter, carbonates, clay minerals, and oxides[3].

Toxic metals are accumulated in plants, and animals fed with these plants will tend to accumulate toxic metals themselves. Although contamination of animal feed by toxic metals cannot be entirely avoided given the prevalence of these pollutants in the environment, there is a clear need for such contamination to be minimized, with the aim of reducing both direct effects on animal health and indirect effects on human health[5]. Toxic effects of metals have been described in animals under relatively low levels of metal exposure[6] and one of the earliest effects is the disruption of trace element metabolism[7]. Pb interacts with calcium (Ca) in the nervous system to impair cognitive development. Cd interacts with $\mathrm{Ca}$ in the skeletal system to produce osteodystrophies. $\mathrm{Pb}$ replaces $\mathrm{Zn}$ on heme enzymes and $\mathrm{Cd}$ replaces $\mathrm{Zn}$ on metallothionein.

The need to reduce toxic metal contamination in animal feed in fact poses a significant problem for agricultural regions located in more-or-less industrialized areas in which animals are reared on locally produced feed. There are many such regions worldwide, including in Bulgaria. The district near the Rhodopi Mountain and the Plovdiv Field has been exposed to the influence of the Non-ferrous Metal Works (NFMW) for a long period of time. In the vicinity of the NFMW near Plovdiv, more than 2,100 ha have been polluted by heavy metals. It is estimated that approximately 460 tons of dust, containing mainly $\mathrm{Pb}$, with less $\mathrm{Zn}$ and $\mathrm{Cd}$, have been annually released into the atmosphere for more than 40 years[8,9]. As a result of the new cleansing facilities built in the NFMW, however, the aerosol pollution in the district has been reduced to a minimum. This makes it extremely appropriate to examine the connection between soil and plants regarding the assimilation of heavy metals. This area possesses high levels of heavy metals in soils and in vegetation[10,11,12].

One type of crop grown in such districts is rapeseed[13,14,15,16)]. Its cultivation is mainly for the production of oil, which is widely applied in the food, soap, textile, paint, and varnish industries, as well as in metallurgy and machine building for production of valuable lubrication oils. Winter rapeseed has high nutritional value and thus can be used for green fodder. Valuable protein groats are obtained through the processing of its seeds, which may then be used in the production of combined fodder.

The transition of heavy metals from this type of fodder into the nourished animals is studied in detail in pigs, cattle, sheep, and goats[17,18,19,20,21,22,23,24,25,26]. Very little is known, however, about the heavy metal content and localization in the organs of rabbits.

The aim of the present work was to evaluate the bioavailability of heavy metals in the soil-plantanimal system. This involved an investigation of the connection between the total quantity and the mobile forms of $\mathrm{Pb}, \mathrm{Cd}, \mathrm{Zn}$, and $\mathrm{Cu}$ in soils of varying levels of contamination; the transition of these metals into rapeseed; and their ingestion by rabbits fed with a rapeseed-dominant food mixture.

\section{MATERIALS AND METHODS}

\section{Soils}

Soils used in this experiment were sampled from the vicinity of the area contaminated by the NFMW near Plovdiv, Bulgaria. Soils were collected from the surface (0- to 20-cm depth and 20- to 40-cm depth) of fields located at different distances $(0.5$ and $15.0 \mathrm{~km})$ from the NFMW. The investigated soils are characterized by alkaline reaction, moderate $\mathrm{CaCO}_{3}$ content, loamy texture, and moderate content of organic matter (Table 1). The soil samples were air dried, homogenized in an agitate mortar, and sieved. A fraction with particle size $<1 \mathrm{~mm}$ was taken for analysis. 
TABLE 1

Soil Properties for Soil Sampled from the NFMW near Plovdiv

\begin{tabular}{lcccccc}
\hline Classification & $\begin{array}{c}\text { Distance } \\
\text { from NFMW } \\
(\mathbf{k m})\end{array}$ & $\begin{array}{c}\text { Depth } \\
(\mathbf{c m})\end{array}$ & $\begin{array}{c}\mathbf{p H} \\
\left(\mathbf{H}_{\mathbf{2}} \mathbf{O}\right)\end{array}$ & $\begin{array}{c}\text { Humus } \\
(\%)\end{array}$ & $\begin{array}{c}\mathrm{CaCO}_{3} \\
(\%)\end{array}$ & $\begin{array}{c}\text { Clay } \\
(\%)\end{array}$ \\
\hline Calcaric & 0.5 & $0-20$ & 7.72 & 2.19 & 7.30 & 29.35 \\
Fluvisol & & $20-40$ & 7.75 & 1.82 & 7.50 & 32.23 \\
Calcaric & 15.0 & $0-20$ & 7.47 & 1.54 & 8.70 & 12.71 \\
Fluvisol & & $20-40$ & 7.62 & 1.01 & 8.94 & 13.82 \\
\hline
\end{tabular}

\section{Plants}

The winter rapeseed (Brassica napus L. a napus) was grown in the same regions situated at different distances $(0.5$ and $15.0 \mathrm{~km})$ from the NFMW - Plovdiv. On reaching the "blossoming" stage, the rapeseed was gathered, and the content of $\mathrm{Pb}, \mathrm{Cd}, \mathrm{Zn}$, and $\mathrm{Cu}$ in the different parts (stems, leaves, and inflorescences) used as fodder for rabbits was quantitatively determined. The samples were treated by the method of dry ashing.

\section{Rabbits}

Rabbits of the breed Belgian Giant were bred in the experimental base of the "Stockbreeding" department at the Agricultural University - Plovdiv. They were fed twice a day (in the morning and in the evening) for a month, with fodder prepared specially for the purpose. Green fodder of rapeseed was added to the concentrated fodder (consisting mainly of barley). The rabbits were divided into two groups, each consisting of 20 animals. The first group was fed with rapeseed grown $0.5 \mathrm{~km}$ away from the NFMW (group A) and the second group was fed with rapeseed grown $15 \mathrm{~km}$ away from the NFMW (group B). Samples (bone, liver, kidney, muscle, and blood) from both groups of rabbits were collected when the animals were slaughtered. The samples were treated by the method of acid digestion.

\section{Heavy Metal Analysis}

\section{Sample Preparation}

\section{Soils}

1. Total content of heavy metals in soils was determined in accordance with the international standard for extraction of trace elements soluble in aqua regia ISO 11466[27]. Three grams of soil sample were decomposed on a sand bath heater for $3 \mathrm{~h}$ with $21 \mathrm{ml}$ of concentrated hydrochloric acid $(\mathrm{HCl})+7 \mathrm{ml}$ of concentrated nitric acid $\left(\mathrm{HNO}_{3}\right)$. After cooling the sample, the residue was transferred into a 50-ml flask and water was added up to the mark.

2. The mobile heavy metal contents have been determined in $0.005 M$ diethylentriaminepentaacetic acid (DTPA) and 0.1 $M$ triethanolamine (TEA) buffered at $\mathrm{pH}$ 7.3[28]. Soil samples were shaken for $2 \mathrm{~h}$ at $20^{\circ} \mathrm{C}$. After shaking, the soil-solution system was centrifuged and filtered. The ratio soil to liquid was $1: 2$ by weight to volume.

3. Fractionation studies - The distribution of heavy metals in the different forms and phases in which they occur in soil can be determined using sequential extraction procedures. Sequential 
extraction procedures provide information about the determination of the relative binding strength of the metal on various solid phases and about their potential reactivity under physicochemical environmental conditions. In the present study, a five-step Tessier sequential extraction scheme[29], separating exchangeable metals, metals bound to carbonates, metals bound to Fe-Mn oxides, metals bound to organic matter, and residual metals, was applied for the extraction of metals in soil samples for assessing the mobility of the metals.

\section{Plants}

A 1-g sample was weighed into a quartz crucible and put into a furnace $\left(400^{\circ} \mathrm{C}\right)$ until ashing occurred. After cooling to room temperature, $1 \mathrm{ml} \mathrm{HNO}_{3}(1: 1)$ was added, evaporated in a sand bath, and put again into the furnace $\left(400^{\circ} \mathrm{C}\right)$. The procedures were repeated until the ash was white. It was finally dissolved in $2 \mathrm{ml} 20 \% \mathrm{HCl}(\mathrm{v} / \mathrm{v})$, transferred into a graduated 25-ml flask, and brought to volume with doubly distilled water.

\section{Rabbits}

1. Liver, kidney, muscle, and blood - A 1-g subsample (2 $\mathrm{ml}$ of blood) was digested with concentrated $\mathrm{HNO}_{3}$ and hydrogen peroxide $\left(\mathrm{H}_{2} \mathrm{O}_{2}\right)$. Digested samples were transferred into a graduated 10-ml flask and diluted with doubly distilled water.

2. Bone - A 5-g sample was placed into a quartz crucible and put into a furnace $\left(400^{\circ} \mathrm{C}\right)$ for $12 \mathrm{~h}$. After cooling to room temperature, $10 \mathrm{ml} \mathrm{HNO}_{3}$ was added and placed on a preheated hot plate and heated until its content was evaporated to 2-3 $\mathrm{ml}$. The digest was cooled, filtrated, and diluted to $25 \mathrm{ml}$ in a calibrated flask.

\section{Equipment}

In order to determine the heavy metal content in the samples, an inductively coupled emission spectrometer (Jobin Yvon Horiba "ULTIMA 2", France) was used. A commercial multielement standard solution (Merck) with concentration $100 \mathrm{mg} / \mathrm{l}$ was used as a stock solution. The calibration standard solutions had the following concentrations: $0,0.2,0.5,2.0$, and $5.0 \mathrm{mg} / \mathrm{l}$. The acidity of the standard and sample solutions was the same.

Certified reference materials (Contaminated Brickworks Soil - ERM CC135a; Apple Leaves SRM1515; and Pig Kidney CRM 186 - BCR Reference Materials) were used for quality control. The results show acceptable agreement between the found and certified values for $\mathrm{Cd}, \mathrm{Cu}, \mathrm{Pb}$; and $\mathrm{Zn}$.

\section{RESULTS AND DISCUSSION}

\section{Soils}

The results (Table 2) showed that with increasing distance from the NFMW - Plovdiv and increasing the depth of the horizon, there was a very clear reduction of the heavy metal content in the soil.

In the soil samples taken from the region situated $0.5 \mathrm{~km}$ away from the NFMW, values for $\mathrm{Pb}$ exceeded the maximum permissible concentrations of $80 \mathrm{mg} / \mathrm{kg}$ for the country: $200.3 \mathrm{mg} / \mathrm{kg}$ in the 0 - to $20-\mathrm{cm}$ layer and $181.8 \mathrm{mg} / \mathrm{kg}$ in the 20 - to $40-\mathrm{cm}$ layer. The region that was $15 \mathrm{~km}$ away from the plants revealed that the concentration of $\mathrm{Pb}$ was reduced by more than $85 \%$, and there was almost no difference between the two horizons. The results obtained for $\mathrm{Zn}$ and $\mathrm{Cd}$ were analogous. In the region of the NFMW, 
TABLE 2

Content of $\mathrm{Pb}, \mathrm{Cu}, \mathrm{Zn}$, and $\mathrm{Cd}(\mathrm{mg} / \mathrm{kg})$ in Soils Sampled from the NFMW

\begin{tabular}{|c|c|c|c|c|c|}
\hline \multirow{2}{*}{$\begin{array}{l}\text { Distance from } \\
\text { NFMW (km) }\end{array}$} & \multirow[t]{2}{*}{ Depth $(\mathrm{cm})$} & $\mathrm{Pb}$ & Cd & $\mathrm{Zn}$ & $\mathrm{Cu}$ \\
\hline & & \multicolumn{4}{|c|}{$(x \pm S D)$} \\
\hline \multirow[t]{2}{*}{0.5} & $0-20$ & $200.3 \pm 6.0$ & $12.2 \pm 0.24$ & $536.1 \pm 4.7$ & $95.7 \pm 1.8$ \\
\hline & $20-40$ & $181.8 \pm 5.1$ & $10.0 \pm 0.18$ & $434.0 \pm 3.2$ & $89.9 \pm 1.7$ \\
\hline \multirow[t]{2}{*}{15.0} & $0-20$ & $24.6 \pm 0.7$ & $2.7 \pm 0.04$ & $33.9 \pm 0.3$ & $16.0 \pm 0.3$ \\
\hline & $20-40$ & $22.7 \pm 0.7$ & $2.5 \pm 0.02$ & $31.9 \pm 0.3$ & $13.9 \pm 0.2$ \\
\hline MPC & & 80 & 2.5 & 340 & 260 \\
\hline
\end{tabular}

Note: $\mathrm{x}$, average value $(\mathrm{mg} / \mathrm{kg})$ from five repetitions; SD, mean standard deviation; MPC, maximum permissible concentration (approved for Bulgaria).

values of $536.1 \mathrm{mg} / \mathrm{kg} \mathrm{Zn}$ and $12.2 \mathrm{mg} / \mathrm{kg} \mathrm{Cd}$ were established, which considerably exceeded the maximum permissible concentrations; although in the more distant region, values of $33.9 \mathrm{mg} / \mathrm{kg} \mathrm{Zn}$ and $2.7 \mathrm{mg} / \mathrm{kg} \mathrm{Cd}$ were measured. Increasing the depth of the soil horizon resulted in a more intense decrease of content to $434.0 \mathrm{mg} / \mathrm{kg} \mathrm{Zn}$ and $10.0 \mathrm{mg} / \mathrm{kg} \mathrm{Cd}$ compared to that of the more distant region, while the differences between the two horizons were negligible. The quantity of $\mathrm{Cu}$ in the soil from the region of the NFMW was $95.7 \mathrm{mg} / \mathrm{kg}$ and at a distance of $15 \mathrm{~km}$ from the NFMW, it decreased considerably to $16.0 \mathrm{mg} / \mathrm{kg}$. The contents of $\mathrm{Cu}$ in the soil from both regions of the investigation were considerably lower than the accepted Bulgarian maximum permissible concentration of $260 \mathrm{mg} / \mathrm{kg}$. Increasing the depth of the horizon exhibited a weak trend of decreasing concentration of $\mathrm{Cu}$ in the soil.

Table 3 presents the results of the mobile forms of $\mathrm{Pb}, \mathrm{Cu}, \mathrm{Zn}$, and $\mathrm{Cd}$ in the examined soils. The percentage contents of the mobile forms in proportion to the total quantity of the elements in the soils are also presented in Table 3. According to the results regarding the mobile forms of the metals, determined by DTPA, the mobile forms of $\mathrm{Cd}$ are $43.4 \%$ of its overall content, while for $\mathrm{Pb}, \mathrm{Cu}$, and $\mathrm{Zn}$ they are $34.8,21.7$, and $17.9 \%$, respectively.

TABLE 3

DTPA-Extractable $\mathrm{Pb}, \mathrm{Cu}, \mathrm{Zn}$, and $\mathrm{Cd}(\mathrm{mg} / \mathrm{kg})$ in Soils Sampled from NFMW

\begin{tabular}{|c|c|c|c|c|c|c|c|c|c|}
\hline \multirow{2}{*}{$\begin{array}{l}\text { Distance } \\
\text { from NFMW } \\
(\mathbf{k m})\end{array}$} & \multirow{2}{*}{$\begin{array}{c}\text { Depth } \\
(\mathrm{cm})\end{array}$} & \multicolumn{2}{|l|}{$\mathrm{Pb}$} & \multicolumn{2}{|l|}{ Cd } & \multicolumn{2}{|l|}{$\mathrm{Zn}$} & \multicolumn{2}{|l|}{$\mathrm{Cu}$} \\
\hline & & $\begin{array}{c}\mathrm{mg} / \mathrm{kg} \\
(\mathrm{x} \pm \mathrm{SD})\end{array}$ & $\%^{*}$ & $\begin{array}{c}\mathrm{mg} / \mathrm{kg} \\
(\mathrm{x} \pm \mathrm{SD})\end{array}$ & $\%$ & $\begin{array}{c}\mathrm{mg} / \mathrm{kg} \\
(\mathrm{x} \pm \mathrm{SD})\end{array}$ & $\%$ & $\begin{array}{c}\mathrm{mg} / \mathrm{kg} \\
(x \pm \mathrm{SD})\end{array}$ & $\%$ \\
\hline \multirow[t]{2}{*}{0.5} & $0-20$ & $69.7 \pm 1.8$ & 34.8 & $5.3 \pm 0.5$ & 43.4 & $95.7 \pm 2.2$ & 17.9 & $20.7 \pm 0.3$ & 21.6 \\
\hline & $20-40$ & $48.9 \pm 1.7$ & 26.9 & $4.1 \pm 0.2$ & 41.1 & $68.6 \pm 2.1$ & 15.8 & $19.5 \pm 0.2$ & 21.7 \\
\hline \multirow[t]{2}{*}{15.0} & $0-20$ & $4.9 \pm 0.1$ & 19.9 & $1.0 \pm 0.02$ & 37.0 & $3.7 \pm 0.1$ & 10.9 & $4.9 \pm 0.2$ & 30.6 \\
\hline & $20-40$ & $4.2 \pm 0.1$ & 18.5 & $0.9 \pm 0.02$ & 36.0 & $3.2 \pm 0.1$ & 10.0 & $4.3 \pm 0.2$ & 30.9 \\
\hline
\end{tabular}

* DTPA-extractable/total content.

$\mathrm{X}$, average value $(\mathrm{mg} / \mathrm{kg})$ from five repetitions; SD, mean standard deviation.

\section{Fractionation of Soil}

Any metals derived from an anthropogenic source are strongly influenced by their form, phase, and oxidation state, and hence, bioavailability. Chemical soil tests are designed to extract a quantity of 
elements from the soil solids that correlate statistically to the size of the "available pool" in the soil defined by the quantity of elements taken by the plants[3]. Chemical extraction techniques provide a wellestablished means of identifying and characterizing different fractions of heavy metals in the soil[30].

Fig. 1 presents mean values (in \%) of metal associated with different fractions (exchangeable metals, metals bound to carbonates, metals bound to Fe-Mn oxides, metals bound to organic matter, and residual metals).

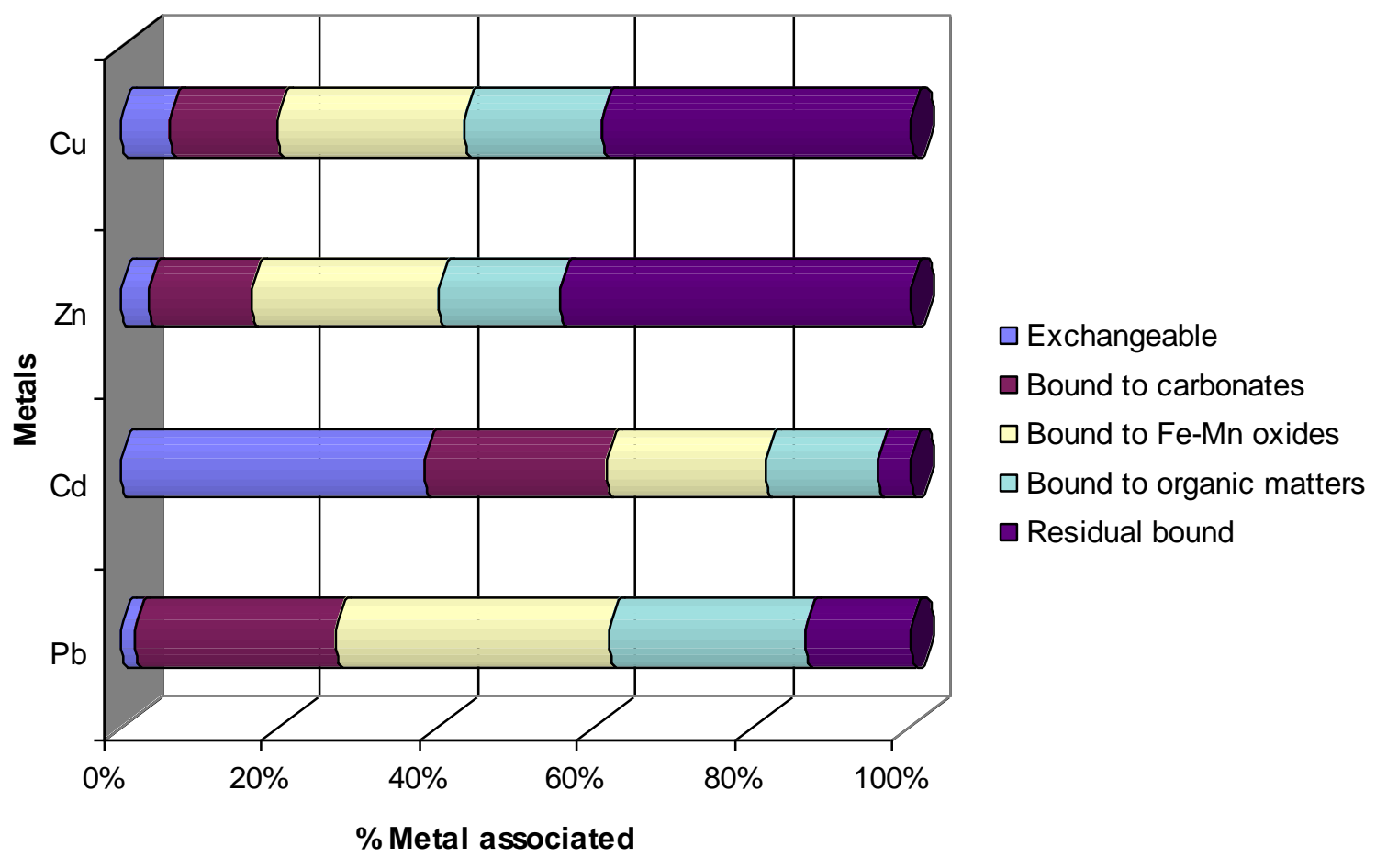

FIGURE 1. Association of metals with different fractions of soils of the study area.

Results of the geochemical partitioning using the Tessier scheme[29] revealed high concentrations of $\mathrm{Cd}$ to be associated with the mobile fraction of the soil. Most of the $\mathrm{Pb}, \mathrm{Cu}$, and $\mathrm{Zn}$ were bound with forms largely unavailable for plants, i.e., Fe-Mn oxides and residual fraction.

Because $\mathrm{Pb}$ binds strongly with organic matter and chemisorbs on oxides of $\mathrm{Fe}, \mathrm{Mn}$, and $\mathrm{Al}$, it is a low-mobility metal in soil. Studies have reported that accumulation of $\mathrm{Pb}$ in plants occurs only with high concentration of $\mathrm{Pb}$ in soils[4,31]. As the soil $\mathrm{Pb}$ concentration was high, the vegetation is prone to accumulate $\mathrm{Pb}[1,3]$.

Based on the fractionation studies, the metals under study can be arranged in decreasing order of bioavailability: $\mathrm{Cd}>\mathrm{Pb}>\mathrm{Cu}>\mathrm{Zn}$.

These results are in accordance with those regarding the mobile forms of the metals as determined by means of DTPA.

\section{Rapeseed}

Table 4 provides the results for the contents of heavy metals in the stems, leaves, and inflorescences of rapeseed used in fodder for the animals. All four elements were mainly concentrated in the inflorescences. In the inflorescences of the rapeseed grown $0.5 \mathrm{~km}$ away from the NFMW, Pb reached up to $10.70 \mathrm{mg} / \mathrm{kg}$, 
TABLE 4

Content of $\mathrm{Pb}, \mathrm{Cd}, \mathrm{Zn}$, and $\mathrm{Cu}(\mathrm{mg} / \mathrm{kg})$ in Rapeseed in the "Blossoming" Stage

\begin{tabular}{|c|c|c|}
\hline & $\begin{array}{l}\text { Grown } 0.5 \mathrm{~km} \text { from } \\
\text { NFMW }(x \pm \text { SD) }\end{array}$ & $\begin{array}{l}\text { Grown } 15 \mathrm{~km} \text { from } \\
\text { NFMW }(x \pm \text { SD) }\end{array}$ \\
\hline \multicolumn{3}{|c|}{$\mathrm{Pb}$ (MPC forage $5.0 \mathrm{mg} / \mathrm{kg}$ ) } \\
\hline Stems & $1.73 \pm 0.1$ & $0.72 \pm 0.02$ \\
\hline Leaves & $8.69 \pm 0.5$ & $1.42 \pm 0.1$ \\
\hline Inflorescences & $10.70 \pm 0.5$ & $3.97 \pm 0.2$ \\
\hline Concentrated fodder (barley) & $0.62 \pm 0.02$ & \\
\hline \multicolumn{3}{|c|}{ Cd (MPC forage $0.5 \mathrm{mg} / \mathrm{kg}$ ) } \\
\hline Stems & $0.11 \pm 0.01$ & $0.02 \pm 0.01$ \\
\hline Leaves & $0.68 \pm 0.02$ & $0.16 \pm 0.01$ \\
\hline Inflorescences & $1.40 \pm 0.05$ & $0.37 \pm 0.02$ \\
\hline Concentrated fodder (barley) & $0.03 \pm 0.01$ & \\
\hline \multicolumn{3}{|c|}{$\mathbf{Z n}$} \\
\hline Stems & $8.90 \pm 0.3$ & $3.55 \pm 0.5$ \\
\hline Leaves & $27.80 \pm 0.5$ & $12.50 \pm 0.4$ \\
\hline Inflorescences & $135.0 \pm 1.1$ & $72.97 \pm 0.9$ \\
\hline Concentrated fodder (barley) & $24.91 \pm 0.5$ & \\
\hline \multicolumn{3}{|c|}{$\mathrm{Cu}$} \\
\hline Stems & $4.94 \pm 0.03$ & $3.12 \pm 0.04$ \\
\hline Leaves & $2.31 \pm 0.04$ & $1.66 \pm 0.05$ \\
\hline Inflorescences & $7.40 \pm 0.08$ & $5.5 \pm 0.03$ \\
\hline Concentrated fodder (barley) & $1.72 \pm 0.04$ & \\
\hline
\end{tabular}

Note: $\quad x$, average value $(\mathrm{mg} / \mathrm{kg}$ ) from five repetitions; SD, mean standard deviation; MPC, maximum permissible concentration (according to Directive 99/29/EC).

$\mathrm{Cd}$ to $1.40 \mathrm{mg} / \mathrm{kg}$, $\mathrm{Zn}$ to $135.0 \mathrm{mg} / \mathrm{kg}$, and $\mathrm{Cu}$ to $7.40 \mathrm{mg} / \mathrm{kg}$, while the more distant region ascertained $3.97 \mathrm{mg} / \mathrm{kg} \mathrm{Pb}, 0.37 \mathrm{mg} / \mathrm{kg} \mathrm{Cd}, 72.97 \mathrm{mg} / \mathrm{kg} \mathrm{Zn}$, and $5.5 \mathrm{mg} / \mathrm{kg} \mathrm{Cu}$.

The content of heavy metals in the rapeseed leaves was lower compared to the inflorescences. In the leaves of rapeseed grown $0.5 \mathrm{~km}$ from the NFMW, $\mathrm{Pb}$ reached up to $8.69 \mathrm{mg} / \mathrm{kg}, \mathrm{Cd}$ to $0.68 \mathrm{mg} / \mathrm{kg}, \mathrm{Zn}$ to $27.80 \mathrm{mg} / \mathrm{kg}$, and $\mathrm{Cu}$ to $2.31 \mathrm{mg} / \mathrm{kg}$, while the more distant region ascertained $1.42 \mathrm{mg} / \mathrm{kg} \mathrm{Pb}, 0.16 \mathrm{mg} / \mathrm{kg}$ $\mathrm{Cd}, 12.50 \mathrm{mg} / \mathrm{kg} \mathrm{Zn}$, and $1.66 \mathrm{mg} / \mathrm{kg} \mathrm{Cu}$.

Considerably lower values were established in the stems of rapeseed. In the stems of rapeseed grown $0.5 \mathrm{~km}$ from the NFMW, Pb reached up to $1.73 \mathrm{mg} / \mathrm{kg}$, Cd to $0.11 \mathrm{mg} / \mathrm{kg}$, $\mathrm{Zn}$ to $8.90 \mathrm{mg} / \mathrm{kg}$, and $\mathrm{Cu}$ to $4.94 \mathrm{mg} / \mathrm{kg}$., while the more distant region ascertained $0.72 \mathrm{mg} / \mathrm{kg} \mathrm{Pb}, 0.02 \mathrm{mg} / \mathrm{kg} \mathrm{Cd}, 3.55 \mathrm{mg} / \mathrm{kg} \mathrm{Zn}$, and $3.12 \mathrm{mg} / \mathrm{kg} \mathrm{Cu}$.

As the distance from the NFMW increased, there was a clear decrease in heavy metal contents in the stems, leaves, and inflorescences of the rapeseed.

The accumulation of $\mathrm{Pb}, \mathrm{Cd}$, and $\mathrm{Zn}$ in the rapeseed organs occurs in the following order: inflorescences $>$ leaves > stems, for the polluted and nonpolluted soils. Only $\mathrm{Cu}$ is an exception to this, as it is the least found in the leaves.

The absorption of heavy metals by the rapeseed has an evident selective preference, as a strong affinity towards $\mathrm{Zn}$ is expressed, especially when considering the low percentage of its mobile forms. However, a direct connection between the quantities of the mobile forms and their content in plants is not observed. 


\section{Rabbits}

Table 5 summarizes the toxic metal levels in the liver, kidneys, muscles, bones, and blood of the rabbits that were fed with a fodder mixture containing rapeseed grown at $0.5 \mathrm{~km}$ (group A) and $15 \mathrm{~km}$ (group B) away from the NFMW.

TABLE 5

$\mathrm{Pb}, \mathrm{Cd}, \mathrm{Zn}$, and $\mathrm{Cu}$ Levels in Bone, Liver, Kidneys, Muscle ( $\mathrm{mg} / \mathrm{kg}$ wet weight), and Blood ( $\mathrm{mg} / \mathrm{l})$ of Rabbits

\begin{tabular}{|c|c|c|c|}
\hline $\begin{array}{l}\text { Organs or } \\
\text { Tissue }\end{array}$ & $\begin{array}{l}\text { Fed with Rapeseed Grown } 0.5 \mathrm{~km} \\
\text { from NFMW (Group A) } \\
(x \pm \text { SD) }\end{array}$ & $\begin{array}{l}\text { Fed with Rapeseed Grown } 15 \text { km } \\
\text { from NFMW (Group B) } \\
(x \pm \text { SD) }\end{array}$ & $\begin{array}{l}\text { Pollution } \\
\text { Factor } \\
\text { (PF) }\end{array}$ \\
\hline \multicolumn{4}{|c|}{$\mathrm{Pb}$ (MPC muscle - $0.1 \mathrm{mg} / \mathrm{kg}$; liver and kidney $-0.5 \mathrm{mg} / \mathrm{kg}$ ) } \\
\hline Bone & $1.0 \pm 0.02$ & $0.32 \pm 0.01$ & 3.12 \\
\hline Liver & $0.65 \pm 0.02$ & $0.40 \pm 0.01$ & 1.63 \\
\hline Kidneys & $3.89 \pm 0.08$ & $1.89 \pm 0.05$ & 2.80 \\
\hline Muscle & $0.19 \pm 0.01$ & $0.11 \pm 0.01$ & 1.73 \\
\hline Blood & $0.43 \pm 0.01$ & $0.36 \pm 0.01$ & 1.19 \\
\hline \multicolumn{4}{|c|}{ Cd (MPC muscle - $0.05 \mathrm{mg} / \mathrm{kg}$; liver - $0.5 \mathrm{mg} / \mathrm{kg}$; kidney $-1.0 \mathrm{mg} / \mathrm{kg}$ ) } \\
\hline Bone & $0.025 \pm 0.002$ & $0.011 \pm 0.001$ & 2.27 \\
\hline Liver & $0.023 \pm 0.002$ & $0.008 \pm 0.001$ & 2.88 \\
\hline Kidneys & $0.077 \pm 0.005$ & $0.035 \pm 0.002$ & 2.20 \\
\hline Muscle & nd & nd & \\
\hline Blood & $0.013 \pm 0.001$ & nd & \\
\hline \multicolumn{4}{|c|}{ Zn (MPC muscle - $50.0 \mathrm{mg} / \mathrm{kg}$; liver and kidney - $80 \mathrm{mg} / \mathrm{kg}$ ) } \\
\hline Bone & $33.13 \pm 0.5$ & $54.50 \pm 0.8$ & 0.61 \\
\hline Liver & $18.72 \pm 0.01$ & $26.65 \pm 0.5$ & 0.70 \\
\hline Kidneys & $13.59 \pm 0.3$ & $1.32 \pm 0.05$ & 10.30 \\
\hline Muscle & $9.99 \pm 0.2$ & $2.19 \pm 0.1$ & 4.65 \\
\hline Blood & $3.14 \pm 0.1$ & $3.76 \pm 0.1$ & 0.86 \\
\hline \multicolumn{4}{|c|}{$\mathrm{Cu}$ (MPC muscle $-5.0 \mathrm{mg} / \mathrm{kg}$; liver and kidney - $60 \mathrm{mg} / \mathrm{kg}$ ) } \\
\hline Bone & $0.65 \pm 0.01$ & $0.71 \pm 0.01$ & 0.91 \\
\hline Liver & $1.48 \pm 0.03$ & $1.47 \pm 0.04$ & 1.01 \\
\hline Kidneys & $1.44 \pm 0.03$ & $1.70 \pm 0.04$ & 0.85 \\
\hline Muscle & $0.66 \pm 0.01$ & $0.11 \pm 0.01$ & 6.00 \\
\hline Blood & $0.45 \pm 0.01$ & $0.52 \pm 0.01$ & 0.87 \\
\hline
\end{tabular}

Note: $\quad \mathrm{x}$, average value $(\mathrm{mg} / \mathrm{kg})$ from five repetitions; SD, mean standard deviation; MPC, maximum permissible concentration (approved for Bulgaria).

In both groups of animals, Cd levels were significantly higher in the kidneys than in the liver and bone. Levels in kidneys and liver were significantly higher than in blood and muscle, as Cd in muscle was below the detection limit. In the blood and all tissues analyzed (Table 4), rabbits from group A displayed significantly higher $\mathrm{Cd}$ levels than the rabbits from group B. Pollution factors (PF), calculated as ratios of the metal levels in the rabbits from group A to the metal levels in rabbits from group B, were 2.88, 2.27, and 2.20 for liver, bone, and kidneys, respectively. 
Several studies have shown that $\mathrm{Cd}$ concentrates more in the kidneys than in the liver[20,26,32,33,34,35,36,37,38,39].

The higher concentration of $\mathrm{Cd}$ in the kidney tissue is due to the detoxification function of the organ where these metals are accumulated[40,41]. Animals exposed to $\mathrm{Cd}$ accumulate it in their liver and kidneys, as their free protein-thiol group content leads to a strong fixation of heavy metals. Despite the excretory mechanism for such metals, which is based on low molecular compounds with -SH groups, vertebrates could not develop these mechanisms during the period of evolution to the extent necessary for today's anthropogenic sources of pollution[35]. The herbivores of terrestrial fauna, birds as well as mammals, demonstrate generally higher renal $\mathrm{Cd}$ than carnivores, since vegetation is contaminated by aerial deposition or by absorption of Cd from the soil[42].

A similar trend was also observed with $\mathrm{Pb}$ levels. The most marked effect of pollution on $\mathrm{Pb}$ levels was seen in the bone $(\mathrm{PF}=3.12)$ and kidneys $(\mathrm{PF}=2.80)$, and to lesser extent in the muscle $(\mathrm{PF}=1.73)$ and liver $(\mathrm{PF}=1.63)$. The difference between $\mathrm{Pb}$ accumulation in the blood of rabbits from group $\mathrm{A}$ and group $\mathrm{B}$ is negligible.

As can be seen from Figs. 2 and 3, the trend of $\mathrm{Pb}$ and $\mathrm{Cd}$ distribution after the introduction of polluted fodder remains unchanged, as the increase of their contents is proportional to the initial levels. The contents of these elements in the organs of the rabbits from group A and group B exhibit a linear relationship, and $\mathrm{R}^{2}$ is more than 0.95 . It is clearly evident that the quantity of accumulation of both elements in all animals' organs is directly associated with diet composition.

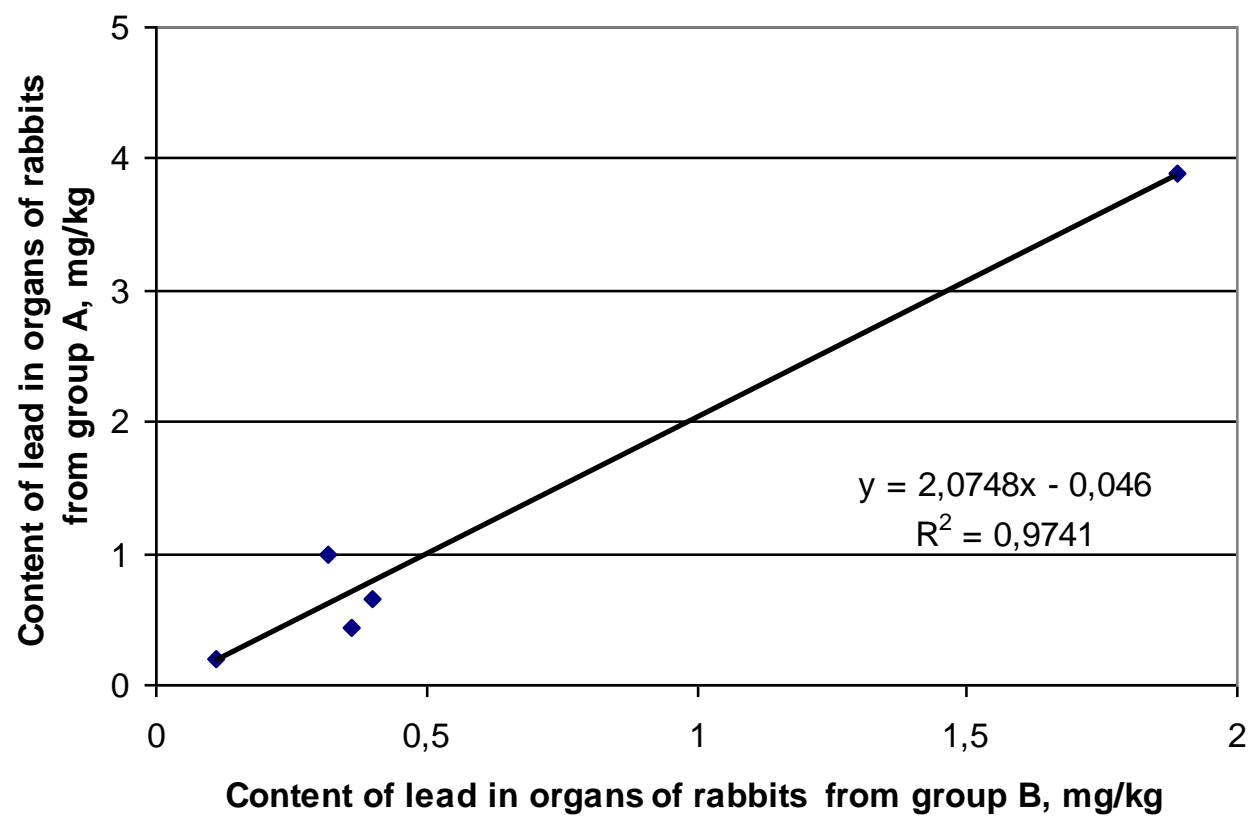

FIGURE 2. Relationship between the content of $\mathrm{Pb}$ in the organs of the rabbits from group $\mathrm{A}$ and group $\mathrm{B}$.

However, this result is the converse of $\mathrm{Cu}$ and $\mathrm{Zn}$, where the content of $\mathrm{Zn}$ in the bones, liver, and blood is comparatively high, and is independent of diet composition. Further, contrary to expectations, its content in the bones, liver, and blood of the rabbits from group A is less than the content in the rabbits from group B. However, a different result is observed in the kidneys and muscle, where PF is 10.3 and 4.65 , respectively. Evidently, in addition to the content of heavy metals in the food of the rabbits, there is a further factor that affects the absorption and distribution of heavy metals within the organs of the animals. 


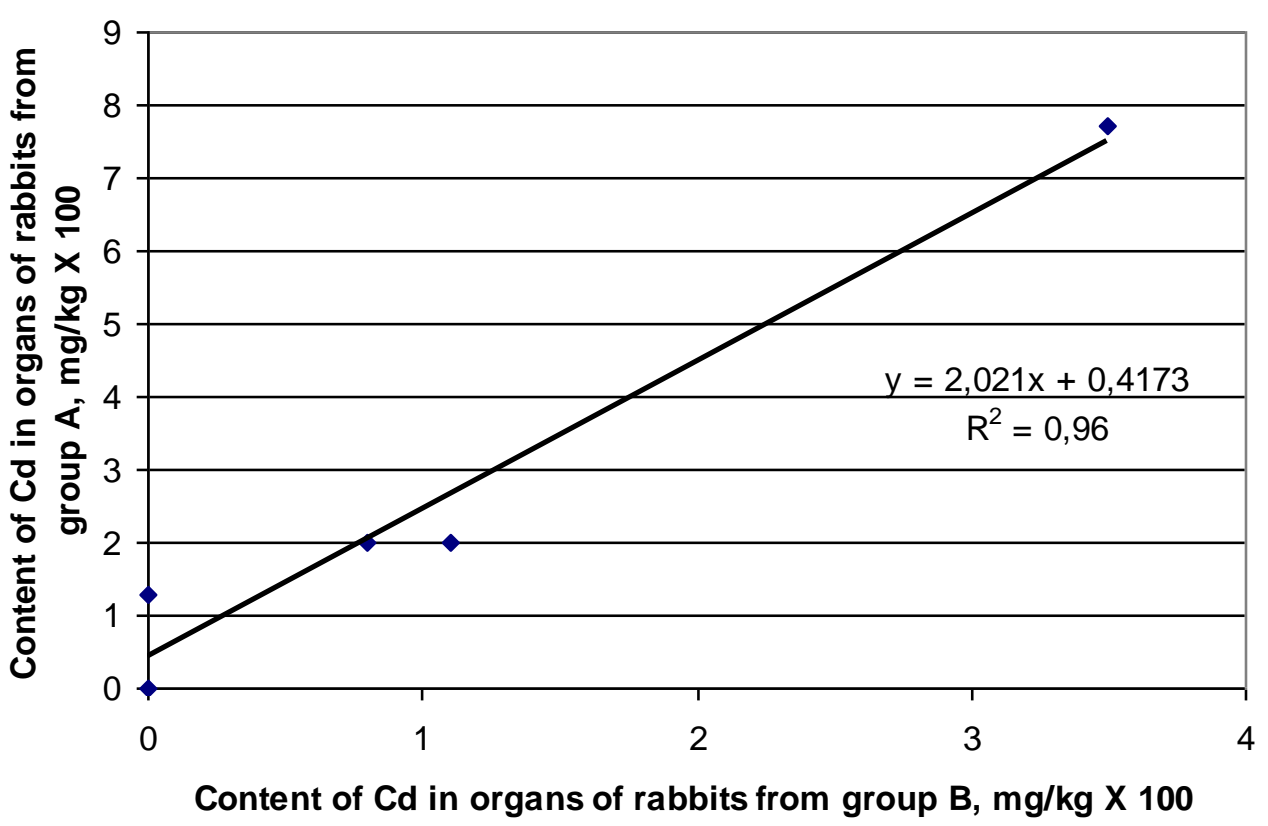

FIGURE 3. Relationship between the content of $\mathrm{Cd}$ in the organs of the rabbits from group $\mathrm{A}$ and group B.

Although the accumulation of $\mathrm{Cu}$ in the organs of the rabbits, in terms of absolute values, is considerably less, a similar trend nevertheless exists, as the diet composition likewise has no effect on the concentration of $\mathrm{Cu}$ in the bones, liver, and blood. PF in the muscle is 6.0. In contrast to $\mathrm{Zn}$, however, in this case there is no observed accumulation of the element in the kidneys.

The results of this study clearly indicate that environmental contamination has a significant impact on heavy metal concentrations in rabbits. Similar results have been reported previously for livestock (cattle, beef, sheep, goat) in other polluted environments, including areas in the vicinity of $\mathrm{Zn}$ refineries[43] and metalliferous areas[24,25,44,45,46,47].

Only broad comparisons can be made between the results of the present study and data reported previously, as there are essentially no existing data on heavy metals levels in rabbit tissue.

The effects of pollution on toxic metal levels in rabbits can be compared with data reported elsewhere for the other animals on the basis of pollution factors (PFs). PF values have been widely used in monitoring studies [48,49] for estimation of the proportion of tissue metal content that has anthropogenic origin. Taking PF values into account, the contribution of pollution to Cd levels in our experiment for rabbits was equivalent to that of other studies of livestock reared close to pollution sources[31,43,46]. This effectively confirms suggestions that the kidney is the primary $\mathrm{Cd}$ storage organ in animals subject to chronic low-level $\mathrm{Cd}$ exposure[50]. For $\mathrm{Pb}$, the effect of pollution in rabbits was more pronounced than in previous studies[31,43,46].

It was found that there was a well-expressed impact of the level of $\mathrm{Cd}$ contamination on the absorption of essential trace metals $(\mathrm{Zn}$ and $\mathrm{Cu})$ and their accumulation into some of the organs of the animals. Rabbits nourished with rapeseed grown $0.5 \mathrm{~km}$ from the NFMW showed significantly lower hepatic $\mathrm{Zn}$ concentrations than rabbits from group B. Similar results have been reported for livestock raised close to $\mathrm{Zn}$ refineries[43,44] as well as in Zn-polluted areas[24,49]. In fact, the low $\mathrm{Zn}$ concentrations in livestock from the industrialized area could also be attributed to the higher Cd exposure. $\mathrm{Cd}$ causes reductions in both intestinal $\mathrm{Zn}$ absorption and hepatic $\mathrm{Zn}$ reserves in cattle[51], as a result of competition for the cation-binding sites of metallothionein[7].

We observed apparently similar effects on the other essential metal, $\mathrm{Cu}$. $\mathrm{Cu}$ levels in the liver of rabbits from groups A and B were almost identical, whereas in blood, kidneys, and bone, they were 
significantly lower in the animals from group A. Decreases in hepatic $\mathrm{Cu}$ levels have been found in livestock from metalliferous and mining areas[43,46,49], and are assumed to be related to chemical interactions between $\mathrm{Cd}$ and $\mathrm{Cu}$. This chemical interaction appears to be very relevant, since hepatic $\mathrm{Cu}$ levels sometimes drop into the deficiency range in areas of severe Cd pollution[43,44,49,52].

\section{CONCLUSIONS}

A comparative research study on the bioavailability of $\mathrm{Pb}, \mathrm{Cd}, \mathrm{Zn}$, and $\mathrm{Cu}$ in the soil-plant-animal system was undertaken. This involved an investigation of the connection between the total quantity and the mobile forms of $\mathrm{Pb}, \mathrm{Cd}, \mathrm{Zn}$, and $\mathrm{Cu}$ in soils of varying levels of contamination; the transition of these metals into rapeseed; and their ingestion by rabbits fed with a rapeseed-dominant food mixture.

It was established that:

1. The uptake of heavy metals by rapeseed has an evident selective preference, as a strong affinity towards $\mathrm{Zn}$ is expressed. The accumulation of $\mathrm{Pb}, \mathrm{Cd}, \mathrm{Zn}$, and $\mathrm{Cu}$ in the organs of the rapeseed occurs in the following order: inflorescences $>$ leaves $>$ stems. A direct relationship between the quantity of the mobile forms and their accumulation in the plants was not found.

2. Environmental contamination has a significant impact on heavy metal concentrations and distribution, as all four trace elements are primarily accumulated in the kidneys and liver. The characteristics of $\mathrm{Pb}$ and $\mathrm{Cd}$ distribution after the introduction of polluted fodder remain unchanged, as the increase of their content is proportional to the initial value. However, this is not valid for $\mathrm{Cu}$ and $\mathrm{Zn}$.

3. There is a well-expressed impact of the level of $\mathrm{Cd}$ contamination on the absorption of essential trace metals $(\mathrm{Zn}$ and $\mathrm{Cu})$ and their accumulation into some of the internal organs of the animals.

\section{REFERENCES}

1. $\quad$ Kabata Pendias, A. (2001) Trace Elements in Soils and Plants. 3rd ed. CRC Press, Boca Raton, FL.

2. Kabata Pendias, A. and Mukherjee, A. (2007) Trace Elements from Soil to Human. Springer-Verlag, Berlin.

3. Adriano, D.C. (2001) Trace Elements in the Terrestrial Environment. Springer-Verlag, Berlin.

4. Alloway, B.J. (1995) Heavy Metals in Soils. Blackie Academic \& Professional, London.

5. SCAN (Scientific Committee on Animal Nutrition) (2003) Opinion of the on Undesirable Substances in Feed, adopted on 20 February 2003, updated on 25 April 2003 (http://europa.eu.int/comm/food/fs/sc/scan/out126_bis_en.pdf).

6. Kostial, K. (1986) Cadmium. In Trace Elements in Human and Animal Nutrition. 5th ed. Mertz W, Ed. San Diego Academic Press. pp. 319-345.

7. Goyer, R.A. (1997) Toxic and essential metal interactions. Annu. Rev. Nutr. 17, 37-50.

8. Anonymous (2002) Bulletin for the Environmental Pollution in Bulgaria. Centre for Ecological Monitoring at Ministry of Environment, Sofia.

9. Anonymous (2003) Bulletin for the Environmental Pollution in Bulgaria. Centre for Ecological Monitoring at Ministry of Environment, Sofia.

10. Bojinova, P., Georgiev, B., Krasteva, V., Chuldjian, H., and Stanislavova, L. (1994) Investigation about the heavy metal pollution in soils and agricultural crops in the region of non-ferrous metal works "D. Blagoev". Soil Sci. Agrochem. Ecol. 4-6, 32-34.

11. Sengalevitch, G. (1999) Problems of heavy metals contamination and using the agricultural lands in the region of KCM - AD - Plovdiv. Prilozenie za ekologia kam bjuletin KCM. 1, 10-17.

12. Angelova, V., Ivanova, R., and Ivanov, K. (2004)Accumulation of lead, cadmium and zinc from contaminated soils to various plants. J. Balkan Ecol. 7, 83-91.

13. Vincenc, J., Belan, F., and Adamec, V. (1995) Risk factors for rape under marginal conditions. Sbornik Jihoceska Univerzita Zemedelska Fakulta, Ceske Budejovice, Fytotechnicka Rada 12, pp. 63-67.

14. Yang, Z., Liu, S., Yang, Z.X., and Liu, S.Q. (2000) Influence of compound pollution of heavy metals on rape. J. Hebei Agric. Univ. 23, 27-30.

15. Rossi, G., Figliolia, A., Socciarelli, S., and Pennelli, B. (2002) Capability of Brassica napus to accumulate cadmium, zinc and copper from soil. Acta Biotechnol. 22, 133-140. 
Angelova, V., Ivanova, R., and Ivanov, K. (2004) Heavy metal accumulation and distribution in oil crops. Commun. Soil Plant Anal. 35, 2551-2566.

Salisbury, C.D.C., Chan, W., and Saschenbrecker, P. (1991) Multielement concentrations in liver and kidney tissues from five species of Canadian slaughter animals. J. Assoc. Anal. Chem. 74, 587-591.

Jorhem, L., Sundstrfm, B., Engman, J., Astrand, C., and Olsson, I. (1996) Levels of certain trace elements in beef and pork imported to Sweden. Food Addit. Contam. 13, 737-745.

Korenekova, B., Nad, P., and Skalicka, M. (1998) The effect of industrial emissions on heavy metal occurrence in organs and tissues of cattle in the vicinity of Kosice. J. Trace Microprobe Tech. 16, 445-452.

Korenekova, B., Skalicka, M., and Nad, P. (2002) Cadmium exposure of cattle after longterm emission from polluted area. Trace Elem. Electrol. 19, 97-99.

Skalicka, M., Korenekova, B., and Nad, P. (2002). Lead in livestock from polluted area. Trace Elem. Electrol. 19, 9496.

Lopez Alonso, M., Benedito, J.L., Miranda, M., Castillo, C., Hernandez, J., and Shore, R.F. (2002) Interactions between toxic and essential trace metals in cattle from a region with low levels of pollution. Arch. Environ. Contam. Toxicol. 42, 165-172.

Lopez Alonso, M., Montana, F.M., Miranda, M., Castillo, C., Hernandez, J., and Benedito, J.L. (2004) Interactions between toxic (As, $\mathrm{Cd}, \mathrm{Hg}$ and $\mathrm{Pb}$ ) and nutritional essential ( $\mathrm{Ca}, \mathrm{Co}, \mathrm{Cr}, \mathrm{Cu}, \mathrm{Fe}, \mathrm{Mn}, \mathrm{Mo}, \mathrm{Ni}, \mathrm{Se}, \mathrm{Zn}$ ) elements in the tissues of cattle from NW Spain. Biometals 17, 389-397.

Miranda, M., Benedito, J.L., Blanco-Penedo, I., Lopez-Lamas, C., Merino, A., and Lopez-Alonso, M. (2009) Metal accumulation in cattle raised in a serpentine-soil area: relationship between metal concentrations in soil, forage and animal tissues. J. Trace Elem. Med. Biol. 23, 231-238.

De Souza, M.V., Vianna, M.W.S, Zandim, B.M., Fernandez, R.B.A., and Fontes, M.P.F. (2009) Heavy metals in cattle biological samples. Ciencia Rural 39, 1774-1781.

Swaileh, K.M., Abdulkhaliq, A., Hussein, R.M., and Matani, M. (2009) Distribution of toxic metals in organs of local cattle, sheep, goat and poultry from the West Bank, Palestinian Authority. Bull. Environ. Contam. Toxicol. 83, 265268.

ISO 11466 (1995) Soil Quality- Extraction of trace elements soluble in aqua regia.

ISO 14870 (2001) Soil Quality- Extraction of trace elements by buffered DTPA solution.

Tessier, A., Campbell, P.G.C., and Bisson, M. (1979) Sequential extraction procedure for the speciation of particulate trace metals. Anal. Chem. 51, 844-850.

Ure, A.M., Davidson, C.M., and Thomas, R.P. (1995) Single and sequential extraction schemes for treemetal speciation in soil and sediments. In Quality Assurance for Environmental Analysis. Quevauviller, P.H., Maier, E.A., and Griepink, B., Eds. Elsevier, Amsterdam. pp. 505-523.

Chary, Sh., Kamala, C.T., and Raj, D.S. (2008) Assessing risk of heavy metals from consuming food grown on sewage irrigated soils and food chain transfer. Ecotoxicol. Environ. Saf. 69(3), 513-524.

Kottferova, J. and Korenekova, B. (1995) The effect of emissions on heavy metals concentrations in cattle from the area of an industrial plant in Slovakia. Arch. Environ. Contam. Toxicol. 29, 400-405.

Koteferova, J. and Korenekova, B. (1999) Distribution of $\mathrm{Cd}$ and $\mathrm{Pb}$ in tissues and organs of free living animals in the territory of Slovakia. Bull. Environ. Contam. Toxicol. 60, 171-176.

Pokorny, B. and Ribaric-Lasnik, C. (2000) Lead, cadmium and zinc in tissue of roe deer (Capreolus capreolus) near the lead smelter Koroska region (Northern Slovenia). Bull. Environ. Contam. Toxicol. 64, 20-26.

Pompe-Gotal, J. and Crnic, A.P. (2002) Cadmium in tissue of roe deer (Capreolus capreolus) in Croatia. Vet. Arh. 72 , 303-310.

Gasparik, J., Massanyi, P., Slamecka, J., Fabis, M., and Jurcik, R. (2004) Concentration of selected metals in liver, kidney and muscle of the red deer (Cervus elaphus). J. Environ. Sci. Health A 39, 2105-2111.

Iwegbue, C.M.A. (2008) Heavy metal composition of livers and kidneys of cattle from southern Nigeria. Vet. Arh. 78, 401-410.

Cai, Q., Long, M.L., Liu, J., Zhu, M., Zhiu, Q.Z., Deng, Y.D., Li, Y., and Tain, Y.J. (2009) Correlations between heavy metals concentration in cattle tissues and rearing environment. Chin. J. Ecol. 27, 202-207.

Nriagu, J., Boughanen, M., Linder, A., Howe, A., Grant, C., Rattray, R., Vutchkov, M., and Lalor, G. (2009) Levels of $\mathrm{As}, \mathrm{Cd}, \mathrm{Pb}, \mathrm{Cu}, \mathrm{Se}$ and $\mathrm{Zn}$ in bovine kidneys and livers in Jamaica. Ecotoxicol. Environ. Saf. 72(2), 564-571.

Aranha, K. (1994) Environmental Chemistry. New Age International, New Delhi. pp. 213-219.

Stoyke, M., Doberschutz, K.D., and Lusky, K. (1995) Heavy metal contents (cadmium, lead and mercury) in selected feedstuff, organs and tissue in cattle found different sites of Brandenburg. Mengen. Spureneler. Arbeitstag 15, 269276.

Peterso, P.J. and Alloway, B.J. (1979) Cadmium in soils and vegetation. In The Chemistry, Biochemstry and Biology of Cadmium. Webb. M., Ed. Elsevier, North Holland, Amsterdam. pp. 45-92.

Spierenburg, T.J., de Graaf, G.J., Baars, A.J., Brus, D.H.J., Tielen, M.J.M., and Arts, B.J. (1988) Cadmium, zinc, lead, and copper in livers and kidneys of cattle in the neighbourhood of zinc refineries. Environ. Monit. Assess. 11, 107114.

Koh, T.S. and Judson, G.J. (1986) Trace elements in sheep grazing near a lead-zinc smelting complex at Port Pirie, South Australia. Bull. Environ. Contam. Toxicol. 37, 87-95. 
45. Zantopoulos, N., Tsoukali-Papadopoulou, H., Epivatianos, P., Nathanael, B., and Mirtsou-Fidani, V. (1990) Lead concentrations in consumable beef tissues. J. Environ. Sci. Health 25, 487-494.

46. Antoniou, V., Zantopoulos, N., and Tsoukali-Papadopoulou, H. (1995) Selected heavy metal concentrations in goat liver and kidney. Vet. Hum. Toxicol. 37, 20-22.

47. Farmer, A.A. and Farmer, A.M. (2000) Concentrations of cadmium, lead and zinc in livestock feed and organs around a metal production centre in eastern Kazakhstan. Sci. Total Environ. 257, 53-60.

48. Sedki, A., Lekouch, N., Gamon, S., and Pineau, A., 2003 Toxic and essential trace metals in muscle, liver and kidney of bovines from a polluted area of Morocco. Sci. Total Environ. 317, 201-205.

49. Miranda, M., Lopez-Alonso, M., Castillo, C., Hernandez, J., and Benedito, J.L. (2005) Effects of moderate pollution on toxic and trace metal levels in calves from a polluted area of northern Spain. Environ. Int. 31, 543-548.

50. Garcia-Fernandez, A.J., Sanchez-Garcia, J.A., Gomez-Zapata, M., and Luna, A. (1996) Distribution of cadmium in blood and tissues of wild birds. Arch. Environ. Contam. Toxicol. 30, 252-258.

51. Smith, R.M., Leach, R.M., Muller, L.D., Griel, L.C., and Baker, D.E. (1991) Effects of long-term dietary cadmium chloride on tissue, milk, and urine mineral concentrations of lactating dairy cows. J. Anim. Sci. 69, 4088-4096.

52. Wentink, G.H., Wensing, T., Baars, A.J., van Beek, H., Zeeuwen, A.A., and Schotman, A.J.H. (1988) Effects of cadmium on some clinical and biochemical measurements in heifers. Bull. Environ. Contam. Toxicol. 40, 131-138.

\section{This article should be cited as follows:}

Angelova, V.R., Ivanova, R.V., Todorov, J.M., and Ivanov, K.I. (2010) Lead, cadmium, zinc, and copper bioavailability in the soil-plant-animal system in a polluted area. TheScientificWorldJOURNAL: TSW Environment 10, 273-285. DOI 10.1100/tsw.2010.33. 


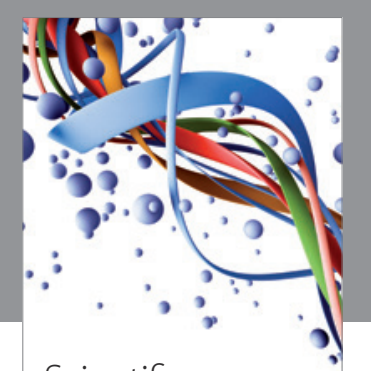

Scientifica
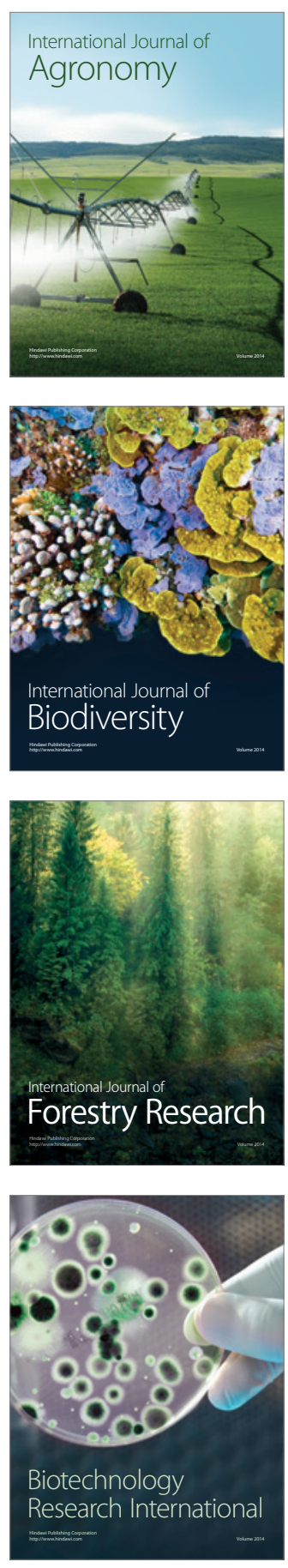
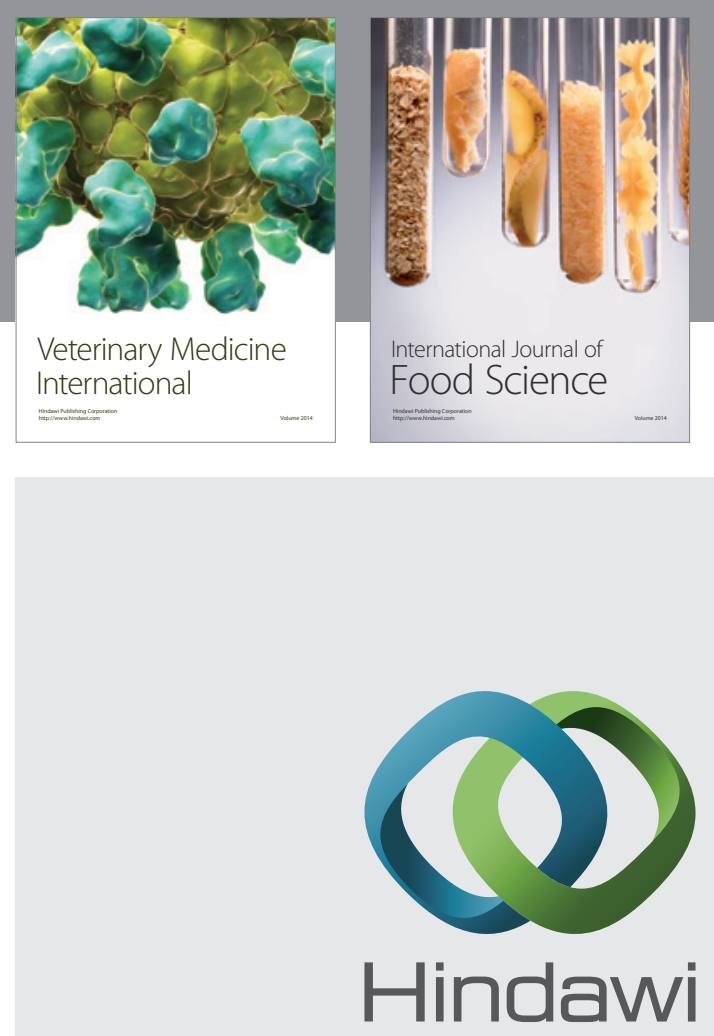

Submit your manuscripts at

http://www.hindawi.com
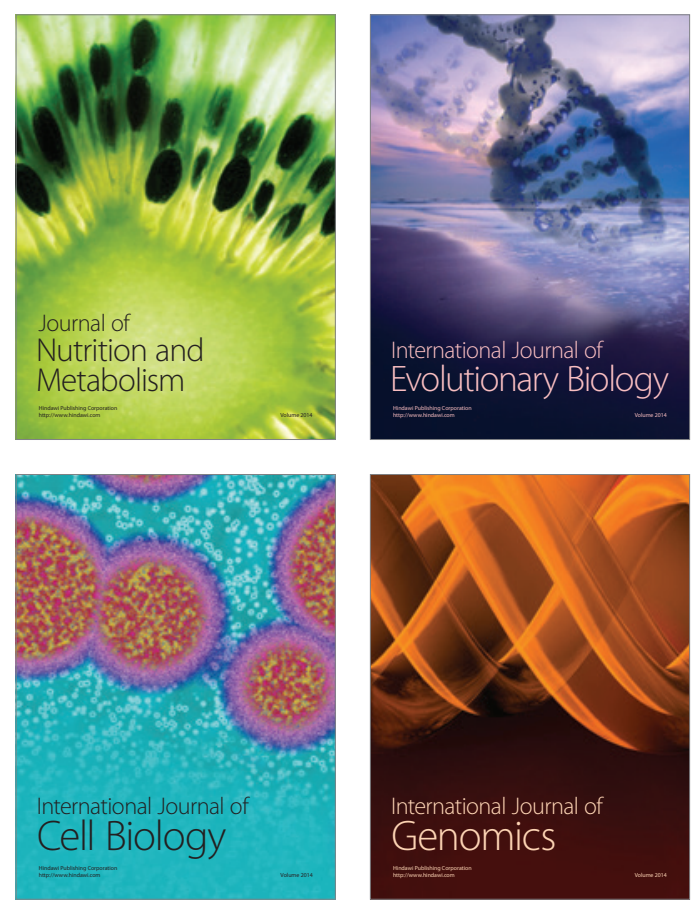
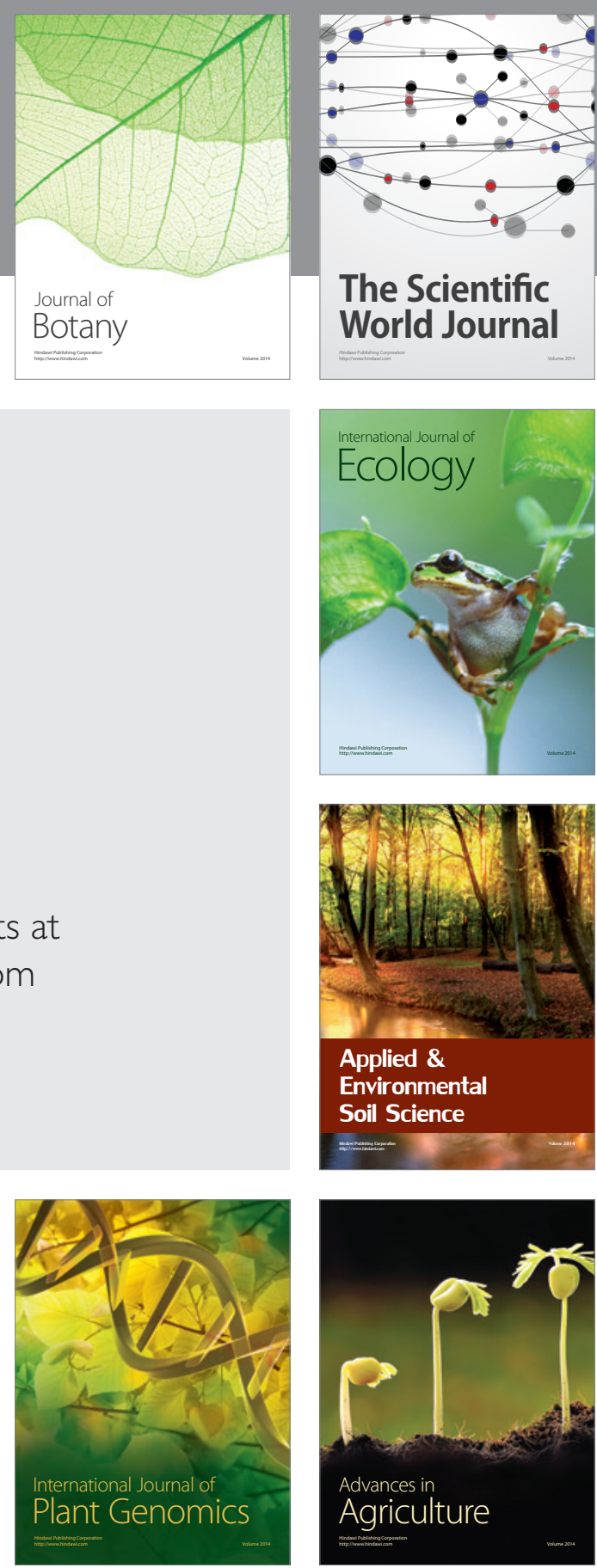

The Scientific World Journal
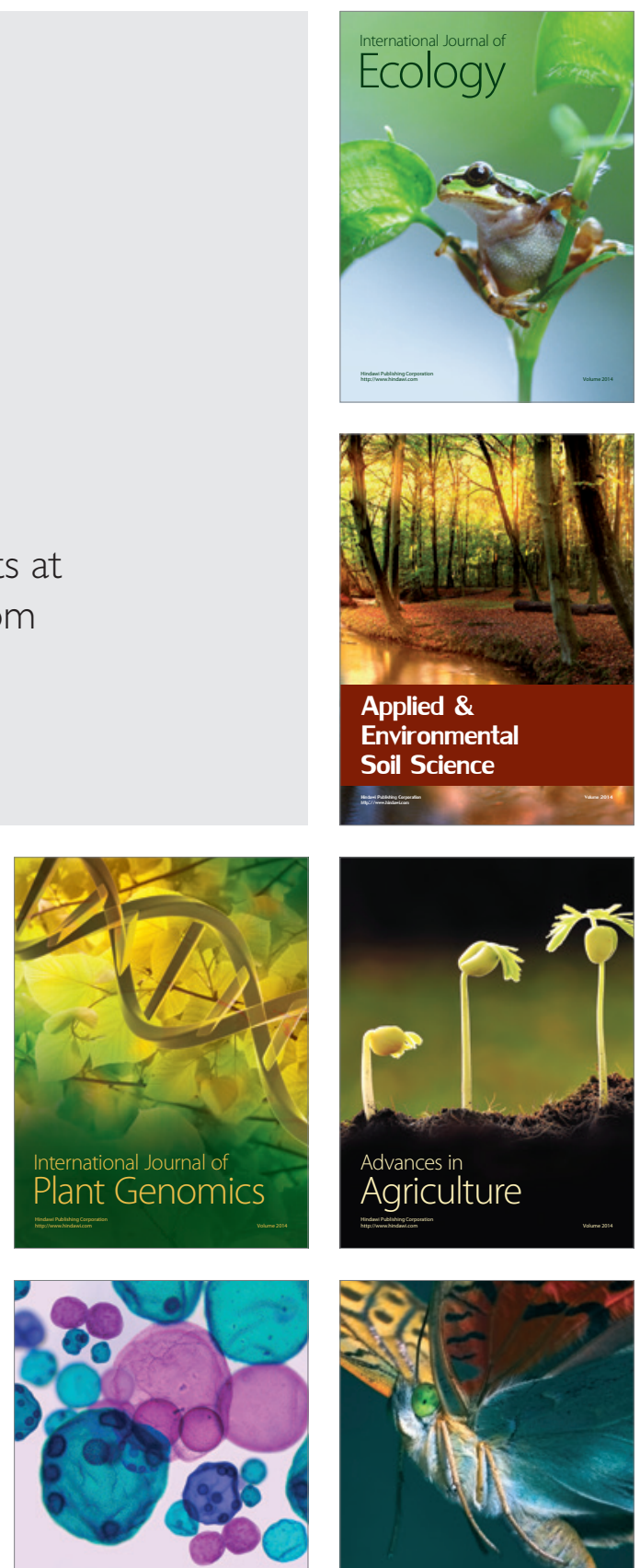

International Journal of Microbiology

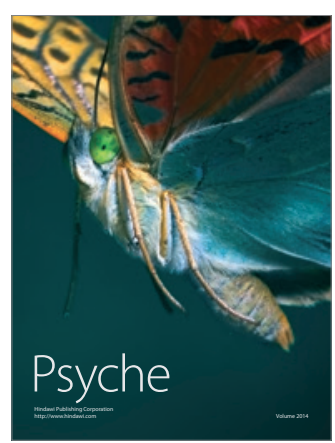

